REGULAR PAPER

\title{
Nesting ecology of East Pacific green turtles at Playa Cabuyal, Gulf of Papagayo, Costa Rica
}

\author{
Pilar Santidrián Tomillo ${ }^{1,2}$, Spencer A. Roberts ${ }^{3}$, Ricardo Hernández ${ }^{4}$, James R. Spotila ${ }^{3}$ \& Frank V. \\ Paladino ${ }^{5}$ \\ 1 Population Ecology Group, Institut Mediterrani d'Estudis Avançats, IMEDEA (CSIC-UIB), Esporles, Spain \\ 2 The Leatherback Trust, Goldring-Gund Marine Biology Station, Playa Grande, Costa Rica \\ 3 Department of Biodiversity, Earth and Environmental Science, Drexel University, Philadelphia, PA, USA \\ 4 Universidad Nacional, Heredia, Costa Rica \\ 5 Department of Biology, Indiana-Purdue University, Fort Wayne, IN, USA
}

\section{Keywords}

Chelonia mydas; conservation; Eastern Pacific; reproductive output.

\section{Correspondence}

Pilar Santidrián Tomillo, Population Ecology Group, Institut Mediterrani d' Estudis Avançats, IMEDEA (CSIC-UIB), Miquel Marquès, 21, 07190, Esporles, Mallorca, Spain.

E-mail: psantidrian@imedea.uib-csic.es

Accepted: 18 February 2014

doi: 10.1111/maec.12159

\begin{abstract}
East Pacific green turtles (Chelonia mydas), often referred to as black turtles, are smaller and exhibit a lower reproductive output than other populations of green turtles in the Atlantic, Indian and Western Pacific Oceans. Knowledge of nesting ecology of East Pacific green turtles is limited to general descriptions. We conducted an exhaustive analysis of the nesting ecology of East Pacific green turtles at Playa Cabuyal, North Pacific Costa Rica. Compared with other populations of green turtles, East Pacific turtles exhibited smaller clutch sizes (mean \pm SD: $76.9 \pm 18.2$ eggs per clutch), but the number of clutches (estimated clutch frequency (ECF): $4.3 \pm 2.3$ clutches) fell within the upper limit reported for green turtles. Clutch size and seasonal reproductive output (409 \pm 135 eggs per female), but not ECF, increased with female size. The observed internesting period (OIP) between consecutive oviposition events (mean \pm SD: $15.4 \pm 2.9$ days) increased as the season progressed and was approximately 2 days longer than the mean OIP reported for the species. Most clutches were laid in the upper vegetated part of beach (zone 3,75\%) and within this zone, tended to be located underneath trees (79\%). Hatching success of clutches laid underneath trees was significantly higher $(0.89 \pm 0.17)$ than that of clutches laid in the exposed areas of zone $3(0.75 \pm 0.33)$. Mean duration of the nesting process $(3: 14 \mathrm{~h})$ was on average 45 min longer than previously reported for the species. Frequency of false crawls was high $(49 \%$ of nesting activities), and nesting success was low (54\% of nesting attempts). Poaching of eggs, tourism and predation by dogs were important threats to this population. Conservation actions were being successfully implemented at the local level due to presence of beach patrollers, but official protection is needed for the preservation of the nesting population into the future.
\end{abstract}

\section{Introduction}

Green turtles (Chelonia mydas) have been extensively studied since Archie Carr's pioneering and prolific work begun in the 1950s (Carr \& Caldwell 1956; Carr \& Hirth 1961; Carr \& Carr 1972; Carr 1975). However, despite the extensive scientific information available today on population biology (Bjorndal 1980; Limpus 1993; Troëng \& Rankin 2005), nesting ecology (Hirth 1980; Bjorndal \& Carr 1989; Broderick \& Godley 1996; Godley et al. 2001) and migratory and diving behavior (Luschi et al. 1998; Hays et al. 2000, 2001) of green turtles, very few studies 
have focused on the Eastern Pacific populations, previously known as black turtles.

Taxonomic classification of black turtles was subject to great controversy for many years (Bowen \& Karl 1999; Grady \& Quattro 1999; Karl \& Bowen 1999; Pritchard 1999; Shrader-Frechette \& McCoy 1999), as some scientists considered them a different species than green turtles due to morphological, geographical and reproductive differences (Bocourt 1868; Figueroa \& Alvarado 1991; Pritchard 1996). However, genetic studies show that there are minimal differences among populations (Karl \& Bowen 1999) and that they are all members of one species.

Populations of leatherback turtles (Dermochelys coriacea) in the Eastern Pacific have smaller body sizes and exhibit lower reproductive outputs (mainly due to smaller clutch sizes) than populations in other ocean basins (Wallace \& Saba 2009). Although similar differences have been reported for green turtles (reviewed by Hirth 1997), detailed studies on the life history of green turtles in the Eastern Pacific are scarce, and little information is available on their population biology and nesting ecology.

Primary nesting grounds of Eastern Pacific green turtles are found in Colola and Maruata beaches in Michoacán, Mexico (Cliffton et al. 1995; Alvarado-Díaz et al. 2003) and the Galapagos Islands, Ecuador (Green \& Ortiz-Crespo 1982; Green 1984), and secondary nesting grounds are found throughout Central America. In Costa Rica, Cornelius (1976) described some aspects of the nesting behavior of green turtles at Playa Naranjo, Santa Rosa National Park, and suggested (Cornelius 1995) that the nesting season for green turtles in Northwest Costa Rica was long and could extend year round. Also in Costa Rica, green turtles stay in the vicinity of the nesting beaches during the internesting period and perform short distance migrations after nesting (Blanco 2010), which may affect their investment in reproduction.

The Gulf of Papagayo is a marine area of high productivity because of frequent occurrence of upwellings (Bianchi 1991; Jiménez 2001). The waters of the Gulf serve as an important internesting habitat for leatherback turtles (Shillinger et al. 2010), foraging grounds for green (Blanco et al. 2012a) and hawksbill turtles (Eretmochelys imbricata; unpublished information), and the beaches of the Gulf are suitable nesting grounds for green turtles, olive ridleys (Lepidochelys olivacea) and leatherback turtles (Cornelius 1976), and are sporadically used by hawksbill turtles.

Playa Cabuyal is an important nesting beach for green turtles in the Gulf of Papagayo but levels of nesting and the nesting ecology of the turtles were unknown. Playa Cabuyal is adjacent to the southern limit of Santa Rosa National Park and has no official protection. Like any other unprotected beaches in Central America, egg poaching has been a common practice for years. Additionally, Cabuyal was a popular destination for national tourism, mainly composed of families that camped on the beach, as the beach was not yet developed. Camping was very common on weekends and during vacation time in the dry season (Christmas, January, Easter and July) until the Ministry of Health forbade it in April 2011.

Here, we conducted an exhaustive analysis of the nesting ecology of green turtles on Playa Cabuyal, Gulf of Papagayo, Northwest Costa Rica, during two full seasons 2011-2012 and 2012-2013 and in the latter part of the 2010-2011 season. We estimated reproductive output, internesting intervals, nesting and hatching success, and described the nesting process for this population. We compared our results with those reported for green turtles in other ocean basins and for other sea turtle species that nest in the area. Finally, we assessed the importance of Cabuyal, as a green turtle nesting site in the Eastern Pacific and discussed the conservation challenges that these turtles may face in the near future.

\section{Study site}

Playa Cabuyal $\left(10^{\circ} 40^{\prime} \mathrm{N}, 85^{\circ} 39^{\prime} \mathrm{W}\right)$ is located on the Gulf of Papagayo, in Northwest Costa Rica (Fig. 1). The site was $1.4 \mathrm{~km}$ long and was a high-energy beach, frequently changing within and between seasons; e.g. the northernmost $200 \mathrm{~m}$ of the beach were lost to erosion in 20112012 after storms in October, and were only redeposited the following season. The north end was rocky with sand patches that were sometimes suitable for nesting. An estuary opened at the south end, associated with a mangrove forest that extended behind most of the beach. There was a little unpaved road behind the beach where vehicles were driven before 2012, which passed through suitable nesting habitat.

\section{Material and Methods}

\section{Beach coverage}

We divided the beach from North to South into $14 \mathrm{sec}-$ tors of $100 \mathrm{~m}$ and in sub-sectors of $25 \mathrm{~m}$. We distinguished three zones from the water to the vegetation line: zone 1: below high tide line, zone 2: between high tide line and vegetation and zone 3 in the vegetation. For zone 3 , we distinguished nests that were laid underneath trees and were in shaded areas, and nests that were laid on low vegetation areas (usually in the grass) and were therefore exposed to the sun.

We partially surveyed season 2010-2011 (15 January 15 2011-29 March 2011) and fully covered the seasons 2011-2012 (1 July 2011-30 April 2012) and 2012-2013 
Fig. 1. Map of Playa Cabuyal and other nearby green turtle (Chelonia mydas) nesting beaches in North Pacific Costa Rica.

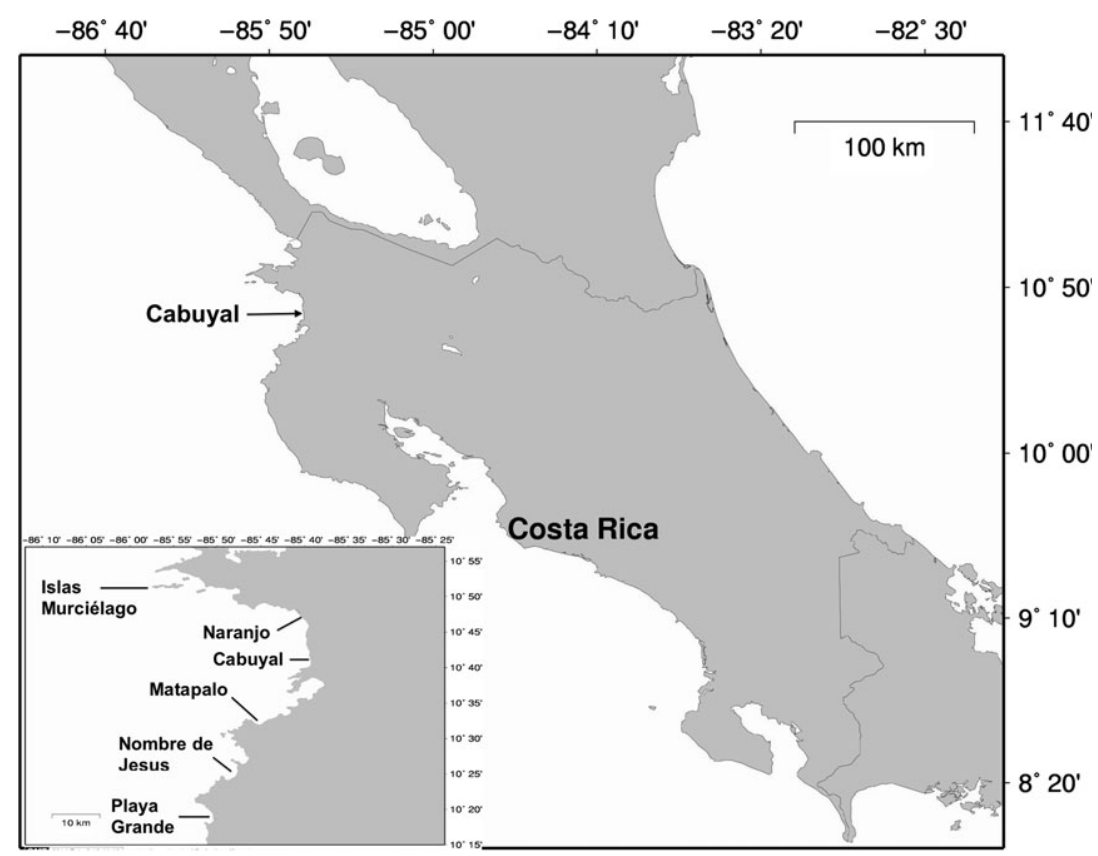

(10 August 2012-10 April 2013). During the peak season (November-March), we patrolled the beach at night between 20:00 and 04:00 $\mathrm{h}$ and during the low season (September, October and April) between 21:00 and 03:00 h. At night, we marked and identified all turtles encountered and recorded all nesting events. In the morning, we counted tracks to account for turtles that could have been missed the previous night and verified successful nesting events when possible. We estimated beach coverage as the number of identified turtles from any evening survey divided by the total number of body pits identified from the morning walks.

\section{Nesting turtles}

When we encountered a turtle, we recorded the local time for each of the following activities: emerging from the ocean, digging body pit, digging egg chamber, laying eggs, covering the nest and returning to the water. We recorded nesting status for each turtle encountered (or track seen when the turtle was missed) as (i) false crawl if the turtle did not make a body pit and returned to the ocean, (ii) aborted nest if the turtle made a body pit but did not lay eggs, (iii) nest if the turtle laid eggs and (iv) body pit if the turtle was missed but a body pit was found (we could not verify if the turtle had nested or aborted the nest). We estimated nesting success by dividing the number of nests by the sum of nests and aborted nests.

After turtles finished laying eggs, we checked for external and PIT tags and marked the turtles if they had none.
We marked turtles with a single PIT (passive integrated transponder) tag and one INCONEL metal tag on the right front flipper after oviposition. The PIT tag is a permanent internal tag that lasted indefinitely and is frequently used in sea turtle research (Dutton \& McDonald 1994; Steyermark et al. 1996). To identify the turtle in subsequent nestings within the same season or subsequent seasons, we used a hand-held AVID PIT scanner. We used PIT tags for the whole duration of the project and INCONEL tags for external identification only in 20122013. After identifying the turtle, we measured her curve carapace length (CCL) and width (CCW) with a flexible measuring tape $( \pm 0.05 \mathrm{~cm})$ and checked whether turtles had any distinguishable characteristics such as scars or the presence of epibionts. We counted eggs with a mechanical counter during oviposition or at relocation time if the clutch was moved for protection.

We defined the observed internesting period (OIP) as the number of days between confirmed nesting events. Previous methodology with leatherback turtles (Reina et al. 2002) excluded values of OIP that were twice as long or longer than the minimum OIP, because the turtle could have been missed in between observed nesting events. We found a seasonal trend in the OIP of black turtles in Cabuyal, with OIPs being longer at the end of the season. To prevent eliminating good values, we calculated the minimum OIP for each fortnight and excluded values that were twice as long or longer than the minimum OIP for that time period. We estimated clutch frequency (ECF) for each turtle by dividing the number of days between her first and last nests by the average OIP 
of the season and added one to account for the first nest (Steyermark et al. 1996; Reina et al. 2002). We defined observed clutch frequency (OCF) as the number of confirmed nests for each turtle. We estimated seasonal reproductive output by multiplying the average number of eggs per clutch by the ECF of each female. We calculated nesting success, OIP, ECF, OCF and seasonal reproductive output for the two full seasons, 2011-2012 and 2012-2013.

\section{Nests}

We marked nests at night during or after oviposition and triangulated the location after the turtles left. To triangulate nests, we measured the distance from the nest to the closest beach marker to the north and to the south. We relocated clutches that were in danger of tidal inundation or of being poached. Clutches were relocated to safer areas of the beach immediately after egg laying. In some instances, clutches were relocated in the morning when the nesting event was missed at night but the eggs could be found in the morning.

We excavated nests to determine hatching success 2 days after observed hatchling emergence in 2012-2013, but excavated them the day after emergence in 20112012 because of the high risk of nests being excavated by people that year. At excavation, we counted the number of shells and classified unhatched eggs into four developmental categories (Santidrián Tomillo et al. 2009). We estimated hatching success using the formula $\mathrm{H}=\mathrm{S} /$ $(\mathrm{S}+\mathrm{U})$, where $\mathrm{S}$ was number of hatched eggshells and $\mathrm{U}$ is number of unhatched eggs. Hatchlings found alive were released after dark.

We used SPSS statistics v. 20.0 (IBM Corp 2011) to conduct statistical analyses. We used $t$-tests to compare differences between seasons in ECF, OCF, hatching success, clutch size and body sizes, and to compare hatching success of nests that were located in shaded and open areas. We used a chi-square test to analyse whether turtles showed preferences among nesting zones and linear regressions to examine the effect of size on the reproductive output.

\section{Results}

Beach coverage was $63 \%, 87 \%$ and $86 \%$ in $2010-2011$, 2011-2012 and 2012-2013, respectively. Green turtles showed a preference to nest in zone $3\left[\chi^{2}\right.$ (2, $\mathrm{n}=395)=307.44, \mathrm{P}<0.001]$ over zones 1 and 2 . We confirmed 395 nests of which 9, 17 and 75\% were dug in zones 1, 2 and 3, respectively. Within zone 3, turtles preferred to nest in locations underneath trees over open grass areas $\left[\chi^{2}(1, \mathrm{n}=262)=90.52, \mathrm{P}<0.001\right]$. Among clutches laid in zone 3,79\% were laid underneath trees and were shaded or partially shaded and $21 \%$ were laid in the low vegetation but in areas exposed to sun (grass).

\section{Nesting females}

We marked 181 black turtles on Cabuyal beach, 148 of them during the two full seasons (72 turtles in 2011-2012 and 76 turtles in 2012-2013), and 33 turtles from our surveys that were conducted only at the end of the 20102011 season. The peak of the nesting season occurred in December-January in 2011-2012 and approximately 1 month earlier in 2012-2013 (Fig. 2). We determined that $49 \%$ and $51 \%$ of turtle encounters were false crawls and nesting attempts (aborted and successful), respectively. Nesting success was 54\%. The mean duration of the whole nesting process was 3:14 h (range 2:15-4:55 h). The mean (range) duration of emergence, digging body pit, digging egg chamber, egg laying and covering the nest were respectively $0: 19 \mathrm{~h} \quad(0: 02-1: 10), \quad 0: 38 \mathrm{~h} \quad(0: 18-$ $3: 13 \mathrm{~h}), 0: 37 \mathrm{~h}(0: 07-1: 22 \mathrm{~h}), 0: 19 \mathrm{~h}(0: 02-1: 13 \mathrm{~h})$ and 1:19 h $(0: 17-2: 40 \mathrm{~h})$.

The OIP (mean \pm SD) was $15.4 \pm 2.9$ days, and was significantly longer in 2011-2012 (16.1 \pm 2.2 days, $\mathrm{n}=109)$ than in 2012-2013 (14.4 \pm 2.8 days, $\mathrm{n}=118$; $\mathrm{P}<0.001)$. In both years the OIP also became longer as the season progressed (Fig. 3; 2011-2012: $\mathrm{r}^{2}=0.388$, $\left.\mathrm{P}<0.001 ; 2012-2013: \mathrm{r}^{2}=0.351, \mathrm{P}<0.001\right)$. The ECF and $\mathrm{OCF}$ (mean $\pm \mathrm{SD}$ ) were respectively $4.3 \pm 2.3$ clutches $(n=120)$ and $3.3 \pm 2.0$ clutches $(n=120)$. The most common ECFs were one and six clutches in 20112012 and 1, 5 and 6 clutches in 2012-2013 (Fig. 4). There were no significant differences in ECF, OCF, clutch size and size of turtles (CCL and CCW) among seasons (all $\mathrm{P}>0.05$ ). The CCL was (mean $\pm \mathrm{SD}$ ) $86.2 \pm 4.7 \mathrm{~cm}$ and CCW was $80.6 \pm 4.9 \mathrm{~cm}(\mathrm{n}=110)$. Turtles laid on average $76.9 \pm 18.2$ eggs per clutch $(n=118)$ and the average seasonal reproductive output was $409 \pm 135$ eggs

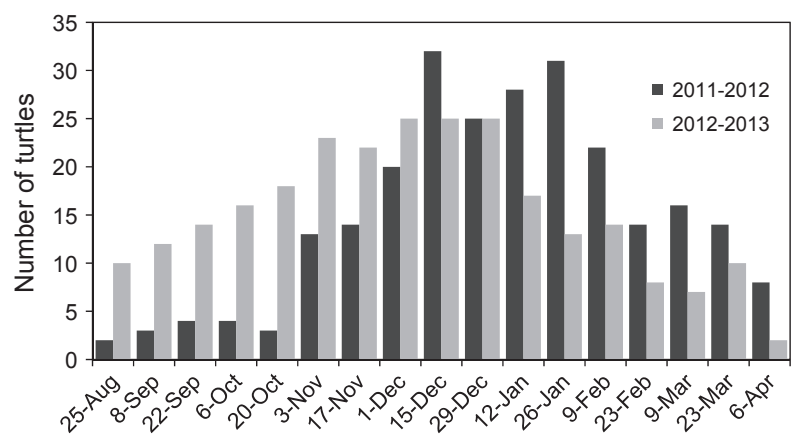

Fig. 2. Chelonia mydas. Temporal distribution of nesting at Playa Cabuyal, Northwestern Costa Rica. Number of individual turtles identified per fortnight at Cabuyal in 2011-2012 and 2012-2013. 

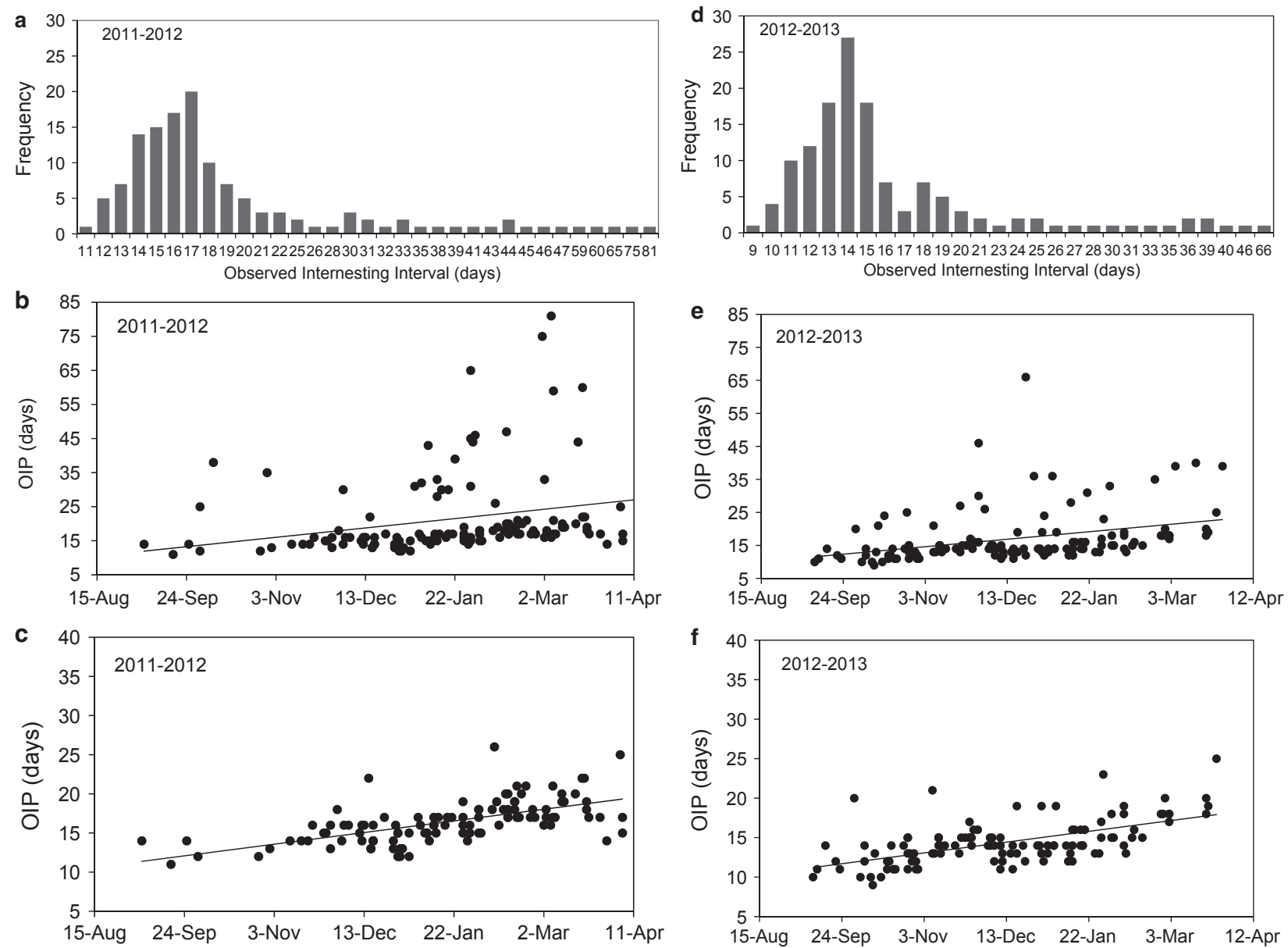

Fig. 3. Chelonia mydas. Observed internesting interval (OIP) at Playa Cabuyal, northwestern Costa Rica in 2011-2012 and 2012-2013. (a, d) OIP frequencies including all observations. $(b, e)$ Seasonal OIP including all observations (2011-2012: $r^{2}=0.065, P=0.003 ; 2012-2013: r^{2}=0.119$, $P<0.001)$. ( $c$, f) Seasonal OIP excluding values that were twice as long or longer than the minimum OIP for each fortnight (2011-2012: $\left.r^{2}=0.388, P<0.001 ; 2012-2013: r^{2}=0.351, P<0.001\right)$.

per female $(n=67)$. Bigger turtles laid bigger clutches $\left(\mathrm{r}^{2}=0.373, \mathrm{P}<0.001\right)$ but not more clutches in the season $(\mathrm{P}=0.972)$. The seasonal reproductive output also increased with size $\left(\mathrm{r}^{2}=0.147, \mathrm{P}=0.006\right)$ (Fig. 5).

\section{Nests}

We marked a total of 298 nests (120 were relocated and 178 remained in situ) during the two full seasons. Most of them were undisturbed during incubation (66\%), 7\% were eroded or inundated by high tides (even after the relocation process), 3\% were poached (eggs taken by people) and $4 \%$ partially poached, $12 \%$ were predated, mainly by dogs (especially during hatchling emergence) and $2 \%$ were excavated by people after hatchling emergence and therefore we could not quantify success. We could not find $6 \%$ of the nests at excavation time (Table 1).
Average hatching success of nests that were unaltered (excluding nests eroded, predated, poached and dug by people) was $0.85 \pm 0.24$ and $0.83 \pm 0.22$ for in situ and relocated nests respectively, but the difference between them was not statistically significant $(\mathrm{P}>0.05)$. There were no significant differences in hatching success between the two seasons $(\mathrm{P}>0.05)$. However, among natural clutches laid in the vegetation area (zone 3), hatching success of nests located in exposed areas $(0.75 \pm 0.33)$ was significantly lower that of nests that were laid underneath trees $(0.89 \pm 0.17$; $\mathrm{P}=0.007$ ). Average depth of nests (bottom egg chamber - surface) and body pits (top of neck of the nest - surface) were $68.1 \pm 7.4$ and $25.6 \pm 6.1 \mathrm{~cm}$, respectively $(n=121)$. The average length of the incubation period was $53.5 \pm 5.2$ days $(\mathrm{n}=94)$. We released a total of 775 hatchlings that were found alive at the excavations. 


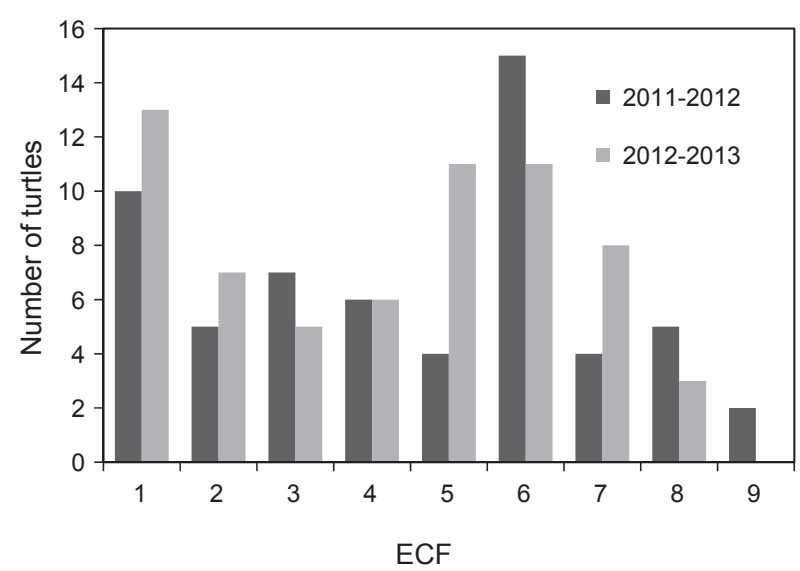

Fig. 4. Chelonia mydas. Number of turtles at Playa Cabuyal, Northwestern Costa Rica versus their estimated clutch frequency (ECF) in 2011-2012 and 2012-2013.

Threats and conservation efforts

Camping (tents, campfires and people) was common on the beach at night when the project started in 2011. We counted a total of 120 tents between 16 January and 27 March in 2011, and a maximum of 39 tents in a single night. The numbers decreased after the Ministry of Health forbade camping before Easter 2011. Poaching of eggs was also a common practice at the beginning of the monitoring efforts. Poachers were frequently identified on the beach at night in 2010-2011 (identified around 33\% of nesting turtles) but their presence was greatly reduced in 2011-2012 and 2012-2013 (poachers were identified around $2 \%$ and $4 \%$ of nesting turtles). Egg poaching was prevented when patrolling teams were present at night, but eggs were also poached during the day, as 3\% and $4 \%$ of the nests were found poached and partially poached, respectively, at the time of excavation (Table 1).

We also observed fishing activities near the beach at night and during the day. Fishing was mainly done with small pangas that operated gillnets in areas close to the mouth of the estuary and to the north end of the beach. In 2010-2011 there was a permanent camp of fishermen settled on the beach that claimed to have been camping in Cabuyal for years during the dry season (DecemberMarch). The Ministry of Health dismantled the camp in February 2011.

\section{Discussion}

We found some differences in the nesting behavior of East Pacific green turtles compared with that of other populations of green turtles and other sea turtle species. A majority of green turtle nests on Playa Cabuyal were placed in zone 3. This behavior is different from that of
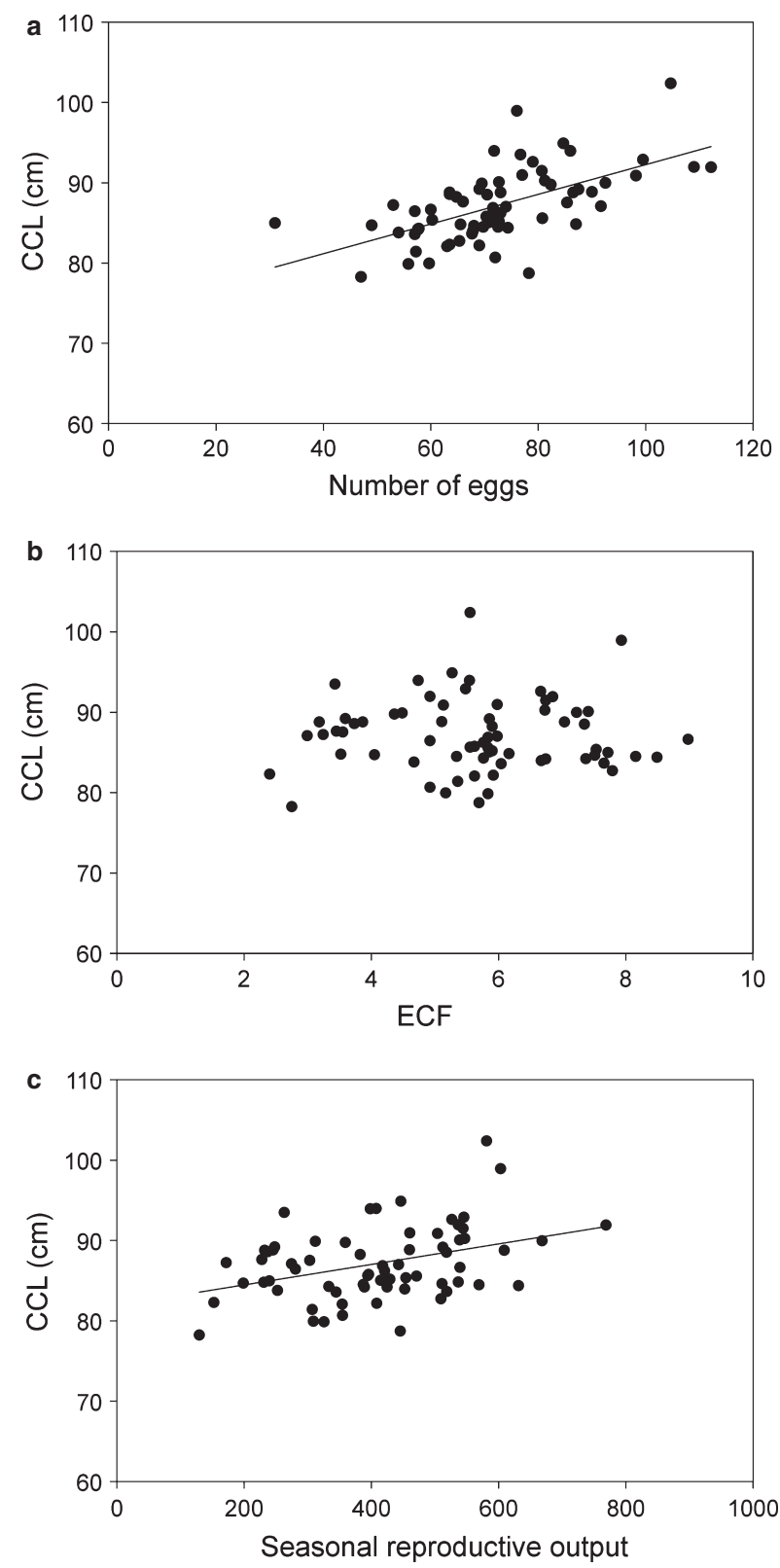

Fig. 5. Chelonia mydas. Relationship between the curve carapace length (CCL) of green turtles at Playa Cabuyal in Northwestern Costa Rica and (a) clutch size $\left(r^{2}=0.373, P<0.001\right)$, (b) estimated clutch frequency (ECF) $(P=0.972)$ and (c) seasonal reproductive output $\left(r^{2}=0.147, P=0.006\right)$.

leatherback and olive ridley turtles that nest in this region, which usually lay their clutches in the open area between the high tide line and the vegetation (Cornelius 1976; Reina et al. 2002). However, it is similar to the nesting behavior of hawksbill turtles, which tend to nest in the vegetation, under bushes or trees, and in areas of low vegetation (Diamond 1976; Kamel \& Mrosovsky 2005; Kamel 2013). The tendency of green turtles in Cab- 
Table 1. Chelonia mydas. Outcome of marked natural and relocated clutches during 2011-2012 and 2012-2013 seasons.

\begin{tabular}{|c|c|c|c|c|}
\hline \multirow[b]{2}{*}{$\begin{array}{l}\text { Outcome of } \\
\text { nests }\end{array}$} & \multicolumn{2}{|l|}{ In situ nests } & \multicolumn{2}{|c|}{ Relocated clutches } \\
\hline & 2011-2012 & 2012-2013 & 2011-2012 & 2012-2013 \\
\hline $\begin{array}{l}\text { Completed } \\
\text { development }\end{array}$ & 39 & 84 & 40 & 34 \\
\hline $\begin{array}{l}\text { Eroded/ } \\
\text { inundated }\end{array}$ & 4 & 8 & 3 & 5 \\
\hline Poached & 2 & 3 & 3 & 1 \\
\hline $\begin{array}{l}\text { Partially } \\
\text { poached }\end{array}$ & 0 & 2 & 9 & 0 \\
\hline Predated & 4 & 16 & 3 & 14 \\
\hline $\begin{array}{l}\text { Excavated by } \\
\text { people }\end{array}$ & 2 & 0 & 4 & 0 \\
\hline Lost & 9 & 5 & 4 & 0 \\
\hline Total & 60 & 118 & 66 & 54 \\
\hline
\end{tabular}

uyal to nest on zone 3 may be explained by the high probability of erosion and tidal inundation of nests laid in zones 1 and 2 on this type of high-energy beach. Risk of erosion and tidal inundation was high in Cabuyal even among nests that were considered to be in safe locations, as $7 \%$ of these clutches (in situ and relocated), were inundated or eroded. Without relocation of doomed clutches, the levels of erosion would have been much higher. Hawksbill turtles also nest in areas with high levels of erosion where hurricanes occur (Mrosovsky et al. 1992; Fortuna \& Hillis 1998); similarly, clutches placed in the vegetation may have a greater probability of survival.

Within zone 3, green turtles in Cabuyal laid most clutches underneath the trees. Hawksbill turtles also exhibited this behavior in Guadeloupe, French West Indies, where high vegetation coverage increased shade and lowered the incubation temperature of developing eggs (Kamel 2013). However, those authors did not find any differences in the hatching success of hawksbill clutches in relation to vegetation coverage in Guadaloupe, and we found that clutches underneath the trees had significantly higher hatching success than clutches placed in the low vegetation area. Several factors may contribute to the optimal environmental conditions experienced by nests located underneath the trees in Cabuyal. For example, lower incubation temperatures, decreased dehydration created by the shade and fewer superficial roots, compared with nests laid in the grass, may all increase the success of clutches laid underneath the trees. Likewise, nesting in the vegetation may also have advantages under future scenarios of sea level rise.

The distribution of the timing of the nesting season or phenology varied between years. In particular, the peak of the nesting season occurred 1 month earlier in 20122013 than in 2011-2012. Changes in the timing of nesting have been related to sea surface temperature (SST) in sea turtles. Increased SST before the onset of the nesting season was related to earlier nesting in loggerhead (Weishampel et al. 2004, 2010; Mazaris et al. 2008) and green turtles (Weishampel et al. 2010). The SST or weather conditions on the nesting beach may also affect nesting phenology in this population. However, this study needs to be extended to include additional seasons and direct analyses need to be performed to test the effect of environmental conditions on the nesting phenology.

The peak of the nesting season for green turtles at Cabuyal was similar to the peak for leatherback turtles nesting on nearby beaches (Reina et al. 2002). However, the nesting season was more protracted, with about 9 months of actual nesting, versus 5 months for the leatherback turtles nesting about $40 \mathrm{~km}$ south at Parque Nacional Marino Las Baulas, and with some levels of nesting possibly occurring during the rest of the year (as suggested by Cornelius 1995). Because green turtles tended to nest underneath trees, conditions may be suitable for development during the hottest months of the year (FebruaryApril), when high temperatures reduce the survival of olive ridley and leatherback turtle embryos in Northwestern Costa Rica (Santidrián Tomillo et al. 2009, 2012; Valverde et al. 2010). Because green turtles in Cabuyal nest in shaded areas, they are able to have longer nesting seasons than other species in the area.

The average length of the nesting process was longer than reported for other sea turtles in the area $(\sim 2 \mathrm{~h}$ for leatherbacks, Reina et al. 2002) and other sea turtles in general (Hirth 1980; Miller 1997). Green turtles at Cabuyal spent on average 45 more minutes on the beach than the average time reported for other green turtles $(\sim 2 \mathrm{~h}$ 30 min, Hirth 1980, 1997). Although Eastern Pacific green turtles are normally perceived as skittish by local biologists, false crawls frequently occurred with and without presence of observers (when only tracks were found), suggesting that human presence was not the main cause of this behavior. Nesting success in Cabuyal was also lower than for leatherback turtles that nest in the area (>90\% in leatherback turtles, Reina et al. 2002) with only $\sim 50 \%$ of the nesting attempts resulting in oviposition. However, this is similar to green and loggerhead turtles in Florida, where a high number of non-nesting emergences ( $50 \%)$ were reported (Weishampel et al. 2003) and in general, this trend has been reported for loggerhead turtles around the world, in which both false crawls and aborted nests are common (Dodd 1988).

Mean OIP reported for green turtles is $\sim 13$ days (range 12-15 days, Hirth 1997), and mean OIP previously reported for green turtles in Santa Rosa National Park (Cornelius 1976) and Mexico (Alvarado-Díaz et al. 2003) was 12 days. The average OIP in Cabuyal was $\sim 2$ days 
longer (15.4 days) than the reported mean for the species. Furthermore, mean OIP recorded at Cabuyal in 20112012 (16.1 days) was the longest mean OIP reported for this species in the synopsis of data for green turtles (Hirth 1997) and later research (Bjorndal et al. 1999; Hays et al. 2002). The length of the internesting interval is affected by water temperature, with shorter IP occurring at high temperatures (Sato et al. 1998; Hays et al. 2002). It is likely that the cold upwelling waters that occur later in the season in the Gulf of Papagayo, increased the OIP of green turtles at Cabuyal towards the second part of the nesting season. Water temperature in the Gulf of Papagayo is warm during the rainy season (May-November) and cold during the dry season (December-April) as a consequence of coastal upwellings (Bianchi 1991; Jiménez 2001). Waters colder than $20^{\circ} \mathrm{C}$ have been registered in this area during the dry season (Bianchi 1991).

The ECF of 4.3 clutches was higher than previously reported for green turtles in Mexico (Alvarado-Díaz et al. 2003) and Costa Rica (Cornelius 1976), and also at the upper limit of ECF reported for other green turtle populations (Hirth 1997). It is possible that green turtles lay more clutches in Cabuyal than at other locations in the Eastern Pacific, but it could also be the result of higher fidelity of turtles to Cabuyal and/or a greater beach coverage. Cabuyal is a smaller beach $(1.4 \mathrm{~km})$ than Naranjo, Costa Rica and Colola, Mexico (both $\sim 5 \mathrm{~km}$ ); it is easy to patrol and we covered the beach for a greater portion of the year compared with the other two locations (Cornelius 1976; Alvarado-Díaz et al. 2003). Additionally, a recent study showed that ECF using ultrasonography (5.1 clutches) was higher than the estimation based on the beach monitoring program at the same site (3.7 clutches). ECF probably was underestimated on the beach, resulting from some level of exchange between nesting beaches and/or relatively low beach coverage (Blanco et al. 2012b).

Clutch size and CCL and CCW were lower than those in other ocean basins, confirming previous reports (reviewed in Hirth 1997). In comparison with Mediterranean green turtles, which are also considered small in size $(\sim 91 \mathrm{~cm} \mathrm{CCL})$, females in Cabuyal laid more clutches (4.3 clutches at Cabuyal versus $\sim 3$ clutches at Cyprus) but fewer eggs per clutch ( 76.9 eggs versus 115 eggs) (Broderick et al. 2003), resulting in similar reproductive outputs. It is possible that the temperate nature of the Mediterranean region constricts the nesting seasons, forcing turtles to lay fewer but bigger clutches in the Mediterranean than the Eastern Pacific. Likewise, the number of eggs increased with size of the turtle at Cabuyal, as well as the seasonal reproductive output, but not the clutch frequency. Similar findings were reported for green and loggerhead turtles in the Mediterranean (Broderick et al.
2003) and in the Eastern Pacific leatherback turtles that nest in the region (Price et al. 2004).

Playa Cabuyal is a nesting beach with medium nesting levels for green turtles ( $\sim 70-75$ females per year). The number of turtles is much lower than at Colola beach, Mexico where current levels are $\sim 1500-2000$ green turtles per season, and where historical records reached $\sim 25,000$ nesting females per year (Delgado-Trejo \& Alvarado Diaz 2012). However, to assess properly the number of turtles in the Northwestern Costa Rican nesting population, the data from Cabuyal need to be combined with information from other adjacent beaches north of the Gulf of Papagayo, where there are beaches with higher numbers of turtles (L. Fonseca, personal communication) and to the south of Papagayo, where nesting occurs but where nesting levels have not been quantified. Additionally, Playa Nombre de Jesús, located further south than the Gulf of Papagayo, also has high levels of nesting, with two to four times the number of turtles observed at Cabuyal (R. Piedra, personal communication). An initial estimate of the nesting population on the beaches for the Costa Rican North Pacific is at least 500-2000 nesting female green turtles. Therefore, we consider the regional nesting population of green turtles in Northwestern Costa Rica an important component of the green turtle metapopulation in the Eastern Pacific Ocean. The advantage of small beaches such as Cabuyal, where the number of turtles is not overwhelming and the beach coverage is high, is that a great proportion of nests and females can be monitored and in-depth nesting ecology studies can be carried out.

\section{Threats and conservation efforts}

Threats to conservation at Cabuyal were similar to those reported elsewhere in Costa Rica. Poaching of eggs, impacts from tourism and domestic animals were common occurrences. Egg poaching was greatly reduced by the presence of patrollers on the beach. However, since a large proportion of beaches in Costa Rica are unprotected (there is no physical presence of guards), poachers that come from the outside can easily move to a different beach where monitoring programs are nonexistent or that have low beach coverage. Therefore, the threat from poaching does not disappear but only moves somewhere else. Some level of poaching, possibly from local inhabitants, still remained after the project started, but poaching levels were much lower. Predation from domestic animals was also high and mainly occurred after hatchling emergence or just prior to emergence from the nest, which still needs to be reduced.

The presence of tourists decreased at night on the beach after the Ministry of Health banned camping, but 
still occurred during the day, mainly on weekends and during the holidays. Unlike most unprotected beaches in Guanacaste, there are no publically known major ongoing plans to develop Cabuyal for regular tourism. However, to preserve the nesting habitat in its existing form, official protection is needed. In conclusion, at the present time, Cabuyal is a suitable nesting beach with medium levels of nesting for green turtles, where conservation actions are starting to be successfully implemented. However, greater protection is needed in the future for preservation and needs to be extended to other beaches where monitoring projects are currently absent or not fully implemented.

\section{Acknowledgements}

We thank Elizabeth Solano, Myriam Norori, Peter Miqueo, don Carlos Guevara, 'don Chente' Guevara, Pablito, and Gabriela Blanco for their contribution to the logistics of the project. Pablo Aguilar, Alberto David Díaz, Lizette Getz and José MacDonald were crucial in the data collection. We also thank Cecilia Mesén from Voluntarios Costa Rica and the volunteers that contributed to the data collection and protection of the beach. Financial support for this study was received from The Leatherback Trust. P. Santidrian Tomillo is funded by a Marie Curie International Incoming Fellowship within the 7th European Community Framework Programme. The study was conducted under research permits from The Guanacaste Conservation Area, MINAET and the animal care committee of Drexel University. We thank Roger Blanco and the Horizontes Biological Station staff for their support of turtle research and conservation in this area. We wish to acknowledge use of the MAPTOOL program for analysis and graphics in this paper. MAPTOOL is a product of seaturtle.org (information is available at www.seaturtle.org). The authors have no conflict of interests to declare.

\section{References}

Alvarado-Díaz J., Arias-Coyotl E., Delgado-Trejo C. (2003) Clutch frequency of the Michoacan green sea turtle. Journal of Herpetology, 37, 183-185.

Bianchi G. (1991) Demersal assemblages of the continental shelf and slope edge between the Gulf of Tehuantepec (Mexico) and the Gulf of Papagayo (Costa Rica). Marine Ecology Progress Series, 73, 121-140.

Bjorndal K.A. (1980) Demography of the breeding population of the green turtle, Chelonia mydas, at Tortuguero, Costa Rica. Copeia, 1980, 525-530.

Bjorndal K.A., Carr A. (1989) Variation in clutch size and egg size in the green turtle nesting population at Tortuguero, Costa Rica. Herpetologica, 45, 181-189.
Bjorndal K.A., Wetherall J.A., Bolten A.B., Mortimer J.A. (1999) Twenty-six years of green turtle nesting at Tortuguero, Costa Rica: an encouraging trend. Conservation Biology, 13, 126-134.

Blanco G.S. (2010) Movements and behavior of the east pacific green turtle (Chelonia mydas) from Costa Rica. $\mathrm{PhD}$ dissertation. Drexel University, USA.

Blanco G.S., Morreale S.J., Bailey H., Seminoff F.V., Spotila J.R. (2012a) Post-nesting movements and feeding grounds of a resident East Pacific green turtle Chelonia mydas population from Costa Rica. Endangered Species Research, 18, 233-245.

Blanco G.S., Morreale S.J., Velez E., Piedra R., Montes W.M., Paladino F.V., Spotila J.R. (2012b) Reproductive output and ultrasonography of an endangered population of East Pacific green turtles. Journal of Wildlife Management, 76, 841-846.

Bocourt M.F. (1868) Description de quelques cheloniens nouveaux appurtenant a la faune mexicaine.@Annales des Sciences Naturelles, Series 5 Zoology, 10, 121-122.

Bowen B.W., Karl S.A. (1999) In war, truth is the first casualty. Conservation Biology, 13, 1013-1016.

Broderick A.C., Godley B.J. (1996) Population and nesting ecology of the green turtle, Chelonia mydas, and the loggerhead turtle, Caretta caretta in northern Cyprus. Zoology in the Middle East, 13, 27-46.

Broderick A.C., Glen F., Goldley B.J., Hays G.C. (2003) Variation in the reproductive output of marine turtles. Journal of Experimental Marine Biology and Ecology, 288, 95-109.

Carr A. (1975) The Ascension Island green turtle colony. Copeia, 1975, 547-555.

Carr A., Caldwell D.K. (1956) The ecology and migrations of sea turtles. 1. Results of field work in Florida, 1955. American Museum Novitates, 1793, 1-23.

Carr A., Carr M.H. (1972) Site fixity in the Caribbean green turtle. Ecology, 53, 45-429.

Carr A., Hirth H. (1961) Social facilitation in green turtle siblings. Animal Behaviour, 9, 68-70.

Cliffton K., Cornejo D.O., Felger R.S. (1995) Sea turtles of the Pacific coast of Mexico. In: Bjorndal K. (Ed). Biology and Conservation of Sea Turtles, revised edn. Smithsonian Institution Press, Washington, DC: 199-209.

Cornelius S.E. (1976) Marine turtle nesting activity at Playa Naranjo, Costa Rica. Brenesia, 8, 1-27.

Cornelius S.E. (1995) Status of sea turtles along the Pacific coast of Middle America. In: Bjorndal K. (Ed). Biology and Conservation of Sea Turtles, revised edn. Smithsonian Institution Press, Washington, DC: 211-219.

Delgado-Trejo C., Alvarado Diaz J. (2012) Current conservation status of the black sea turtle in Michoacán, México. In: Seminoff J.A., Wallace B.P. (Eds). Sea Turtles of the Eastern Pacific: Advances in Research and Conservation. University of Arizona Press, Tucson: 263-278. 
Diamond A.W. (1976) Breeding biology and conservation of hawksbill turtles Eretmochelys imbricata, on Cousin Island, Seychelles. Biological Conservation, 9, 199-215.

Dodd C.K. (1988) Synopsis of the biological data on the loggerhead sea turtle Caretta caretta (Linnaeus 1758). US Fish and Wildlife Service Biological Report 88 (14): 110 pp.

Dutton P.H., McDonald D. (1994) Use of pit tags to identify adult leatherbacks. Marine Turtle Newsletter, 67, 13-14.

Figueroa A., Alvarado J. (1991) Morphometric comparison of the Chelonia populations of Michoacan, Mexico, and Tortuguero, Costa Rica. In: Richardson T.H., Donnelly M. (Eds), Technical Memorandum (NMFS-SEFC) 278. National Oceanic and Atmospheric Administration, Washington, DC: 179-182.

Fortuna J.L., Hillis Z.M. (1998) Hurricanes, habitat loss, and high temperatures: implications for hawksbill hatch success at Buck Island Reef National Monument. Epperly S.P., Braun J. (comp). In: Epperly S.P., Braun J. (Eds), NOAA Tech. Memo. NMFS-SEFSC-415. Miami: 183-185.

Godley B.J., Broderick A.C., Hays G.C. (2001) Nesting of green turtles (Chelonia mydas) at Ascension Island, South Atlantic. Biological Conservation, 97, 151-158.

Grady J.M., Quattro J.M. (1999) Using character concordance to define taxonomic conservation units. Conservation Biology, 13, 1004-1007.

Green D. (1984) Long-distance movements of Galapagos green turtles. Journal of Herpetology, 18, 121-130.

Green D., Ortiz-Crespo F. (1982) Status of Sea Turtle Populations in the Central Eastern Pacific. In: Bjorndal K. (Ed). Biology and Conservation of Sea Turtles. Smithsonian Institution Press, Washington, DC: 221-233.

Hays G.C., Adams C.R., Broderick A.C., Godley B.J., Lucas D.J., Metcalfe J.D., Prior A.A. (2000) The diving behaviour of green turtles at Ascension Island. Animal Behaviour, 59, 577-586.

Hays G.C., Åkesson S., Broderick A.C., Glen F., Godley B.J., Luschi P., Martin C., Metcalfe J.D., Papi F. (2001) The diving behaviour of green turtles undertaking oceanic migration to and from Ascension Island: dive durations, dive profiles and depth distribution. Journal of Experimental Biology, 204, 4093-4098.

Hays G.C., Broderick A.C., Glen F., Godley B.J., Houghton J.D.R., Metcalfe J.D. (2002) Water temperature and interesting intervals for loggerhead (Caretta caretta) and green (Chelonia mydas) sea turtles. Journal of Thermal Biology, 27, 429-432.

Hirth H.F. (1980) Some aspects of the nesting behaviour and reproductive biology of sea turtles. American Zoologist, 20, 507-523.

Hirth H.F. (1997) Synopsis of the biological data on the green turtle Chelonia mydas (Linnaeus 1758). US Fish and Wildlife Service Biological Report 97 (1): 120 pp.

IBM Corp. 2011. IBM SPSS Statistics for Windows, Version 20.0, IBM Corp, Armonk, NY.

Jiménez C. (2001) Seawater temperature measured at the surface and at two depths (7 and $12 \mathrm{~m})$ in one coral reef at
Culebra Bay, Gulf of Papagayo, Costa Rica. Revista de Biología Tropical, 49, 153-161.

Kamel S.J. (2013) Vegetation cover predicts temperature in nests of the hawksbill sea turtle: implications for beach management and offspring sex ratios. Endangered Species Research, 20, 41-48.

Kamel S.J., Mrosovsky N. (2005) Repeatability of nesting preferences in the hawksbill sea turtle, Eretmochelys imbricata, and their fitness consequences. Animal Behaviour, 70, 819-828.

Karl S.A., Bowen B.W. (1999) Evolutionary significant units versus geopolitical taxonomy: molecular systematics of an endangered sea turtle (Genus Chelonia). Conservation Biology, 13, 990-999.

Limpus C.J. (1993) The green turtle, Chelonia mydas, in Queensland: breeding males in the southern Great Barrier Reef. Wildlife Research, 20, 513-523.

Luschi P., Hays G.C., Del Seppia C., Marsh R., Papi F. (1998) The navigational feats of green sea turtles migrating from Ascension Island investigated by satellite telemetry. Proceedings of the Royal Society B: Biological Sciences, 1412, 2279-2284.

Mazaris A.D., Kallimanis A.S., Sgardelis S.P., Pantis J.D. (2008) Do long-term changes in sea surface temperature at the breeding areas affect the breeding dates and reproductive performance of Mediterranean loggerhead turtles? Implications for climate change. Journal of Experimental Marine Biology and Ecology, 367, 219-226.

Miller J.D. (1997) Reproduction in sea turtles. In: Lutz P.L., Musick J.A. (Eds). The Biology of Sea Turtles. CRC Press, Boca Raton, FL: 51-81.

Mrosovsky N., Bass A., Corliss L.A., Richardson J.I., Richardson T.H. (1992) Pivotal and beach temperatures for hawksbill turtles nesting in Antigua. Canadian Journal of Zoology, 70, 1920-1925.

Price E.R., Wallace B.P., Reina R.D., Spotila J.R., Paladino F.V., Piedra R., Vélez E. (2004) Size, growth, and reproductive output of adult female leatherback turtles Dermochelys coriacea. Endangered Species Research, 1, 41-48.

Pritchard P.C.H. (1996) Evolution, phylogeny, and current status. In: Lutz P.L., Musick J. (Eds), The Biology of Sea Turtles. CRC Press, Boca Raton, FL: 1-28.

Pritchard P.C.H. (1999) Stauts of the black turtle. Conservation Biology, 13, 1000-1003.

Reina R.D., Spotila J.R., Mayor P.A., Piedra R., Paladino F.V. (2002) Nesting ecology of the leatherback turtle, Dermochelys coriacea, at Parque Nacional Marino Las Baulas, Costa Rica: 1988-89 to 1999-2000. Copeia, 2002, 653-664.

Santidrián Tomillo P., Wallace B.P., Suss J.S., Magrini K.D., Blanco G., Paladino F.V., Spotila J.R. (2009) Influence of emergence success on the annual reproductive output of leatherback turtles. Marine Biology, 156, 2021-2031. 
Santidrián Tomillo P., Saba V.S., Blanco G.S., Stock C.A., Paladino F.V., Spotila J.R. (2012) Climate driven egg and hatchling mortality threaten survival of Eastern Pacific leatherback turtles. PLoS ONE, 7, e37602.

Sato K., Matsuzawa Y., Tanaka H., Bando T., Minamikawa S., Sakamoto W., Naito Y. (1998) Internesting intervals for loggerhead turtles, Caretta caretta, and green turtles, Chelonia mydas, are affected by temperature. Canadian Journal of Zoology, 76, 1651-1662.

Shillinger G.L., Swithenbank A.M., Bograd S.J., Bailey H., Castelton M.R., Wallace B.P., Spotila J.R., Paladino F.V., Piedra R., Block B.A. (2010) Identification of high-use internesting habitats for Eastern Pacific leatherback turtles: role of the environment and implications for conservation. Endangered Species Research, 10, 215-232.

Shrader-Frechette K., McCoy E.D. (1999) Molecular systematics, ethics and biological decision making under uncertainty. Conservation Biology, 13, 1008-1012.

Steyermark A.C., Williams K., Spotila J.R., Paladino F.V., Rostal D.C., Morreale S.J., Koberg M.T., Arauz R. (1996) Nesting leatherback turtles at las Baulas National Park, Costa Rica. Chelonian Conservation Biology, 2, 173183.
Troëng S., Rankin E. (2005) Long-term conservation efforts contribute to positive green turtle Chelonia mydas nesting trend in Tortuguero, Costa Rica. Biological Conservation, 121, 111-116.

Valverde R.A., Wingard S., Gómez F., Tordoir M.T., Orrego C.M. (2010) Field lethal incubation temperature of olive ridley sea turtle Lepidochelys olivacea at a mass nesting rookery. Endangered Species Research, 12, 77-86.

Wallace B.P., Saba V.S. (2009) Environmental and anthropogenic impacts on intra-specific variation in leatherback turtles: opportunities for targeted research and conservation. Endangered Species Research, 7, 11-21.

Weishampel J.F., Bagley D.A., Llewellyn M., Ehrhard T., Rodenbeck B.L. (2003) Spatiotemporal patterns of annual sea turtle nesting behaviors along an East Central Florida beach. Biological Conservation, 110, 295-303.

Weishampel J.F., Bagley D.A., Ehrhart L.M. (2004) Earlier nesting by loggerhead sea turtles following sea surface warming. Global Change Biology, 10, 1425-1428.

Weishampel J.F., Bagley D.A., Ehrhart L.M., Weishampel A.C. (2010) Nesting phenologies of two sympatric sea turtle species related to sea surface temperatures. Endangered Species Research, 12, 41-47. 